\title{
Association between Zelus versicolor (Herrich-Schäffer) (Hemiptera, Reduviidae, Harpactorinae) and Bidens rubifolia Kunth (Asterales, Asteraceae)
}

\author{
Hélcio R. Gil-Santana1 ${ }^{\bowtie}$ \& Ruy José Válka Alves ${ }^{2}$
}

1. Laboratório de Diptera, Instituto Oswaldo Cruz, e-mail: helciogil@uol.com.br; helciogil@ioc.fiocruz.br (Autor para correspondência ${ }^{\bowtie}$ ). 2. Universidade Federal do Rio de Janeiro, Museu Nacional, Departamento de Botânica, e-mail: ruyvalka@yahoo.com.

EntomoBrasilis 4 (1): 30-32 (2011)

Abstract. The association between the assassin bug Zelus versicolor (Herrich-Schäffer) (Hemiptera, Reduviidae, Harpactorinae) and the plant Bidens rubifolia Kunth (Asterales, Asteraceae) is related.

Keywords: Brazil; Harpactorini; Meliponini

\section{Associação entre Zelus versicolor (Herrich-Schäffer) (Hemiptera, Reduviidae, Harpactorinae) e Bidens rubifolia Kunth (Asterales, Asteraceae)}

Resumo. Relata-se a associação entre o percevejo predador Zelus versicolor (Herrich-Schäffer) (Hemiptera, Reduviidae, Harpactorinae) e a planta Bidens rubifolia Kunth (Asterales, Asteraceae).

Palavras-chave: Brasil; Harpactorini; Meliponini

$\mathbf{R}$ eduviidae is the second largest family of true bugs (Hemiptera, Heteroptera) and all its members are predators; the Triatominae are distinctive for their blood-sucking habits (SchuH \& SLATER 1995). Despite the lack of consensus about the suprageneric classification of Reduviidae, more than 20 subfamilies are recognized (SCHUH \& SLATER 1995). Harpactorinae is the largest subfamily and is represented by the tribes Apiomerini and Harpactorini in the New World. Members of Harpactorinae are commonly associated with plants crops and some have been studied as biological control agents of crop pests (Forero et al. 2008). Harpactorini is the most diversified Reduviidae Group, with 50 genera recognized in the Neotropical Region (Gil-SANTANA \& Forero 2009). There is a need for a revision of the species of the speciose genus Zelus Fabricius Worldwide. CAPRILES (1990) recognized 59 species in this genus. HART $(1986,1987)$ treated the species found in North America and West Indies, but most of the species in Central and South America remain unrevised.

For a long time, the female of the species Zelus versicolor (Herrich-Schäffer) assassin bug had been considered as another taxon, Zelus nigrispinus (Herrich-Schäffer). Only recently, the synonymy between them was formally established by GIL-SANTANA (2008). Z. versicolor has a marked sexual dimorphism (Figs. 1-4, 5), and females show considerable color variation (e. g., Figures 1, 3-4), as do some other species of Zelus (GIL-SAnTana 2008). Several observations have shown that certain Harpactorinae are associated with particular plants. These polyphagous predators often live on a single plant, not only as adults but also sometime as immature instars and eggs. While seeking prey, some Harpactorinae apparently found certain plants to have other advantages, and became adapted to visiting these plants species exclusively. In addition to the prey itself, these plants provide other sources of food, rich in sugars, produced by extrafloral nectaries or other structures (BÉREnger \& Pluot-Sigwalt 1997).
Miller (1956) believed that a close study the plantinsect relationships of Cosmoclopius spp. (Harpactorinae) would be of value in order to deduce the speciation processes in this interesting genus of predatory bugs.

BÉREnger \& Pluot-SigWAlt (1997) recorded that Zelus araneiformis Haviland can achieve complete postembryonic development on glandular formations of Cecropia obtusa Tréc. (Cecropiaceae) and furnished a synopsis of the literature on observations about Harpactorinae associated to plants.

The association of $Z$. versicolor and Bidens rubifolia Kunth is presented here for the first time.

The field observations were made in the city of Nova Friburgo ( $22^{\circ} 17^{\prime} \mathrm{S}$; $42^{\circ} 29^{\prime} \mathrm{W}$, ca. $1000 \mathrm{~m}$ a. s. l.), Rio de Janeiro State, Brazil, between the months of October to May of the years of 1999-2000, 2002-2003 and 2004-2005, in a total area sampled of about $5.000 \mathrm{~m}$. The area studied presents fragments of secondary forest with native and exotic herbaceous and arboreal species such as Eucalyptus sp. (Myrtaceae). Five transects were established in the area and they were walked, slowly, in the morning and/or afternoon, three times per week in the period mentioned above. The insects were observed alive and the observations registered.

In the study area were observed from $B$. rubifolia flowers between March and April.

The insect species was identified following HERRICHSchäffer (1848), Hart (1972) and Gil-Santana (2008). The host plant was identified by comparision with material at the herbarium $\mathrm{R}$ and the assistance of the specialist Jimi Naoki Nakajima from the Universidade Federal de Uberlândia. Voucher specimens are deposited at Museu Nacional, Universidade Federal do Rio de Janeiro, Brazil, respectively in the entomological collection (MNRJ) and herbarium (R).

A total of 47 females, 27 males and 15 nymphs of $Z$. versicolor were observed alive in the area studied. All but one 
female were on individuals of $B$. rubifolia. It's important to notice that the individuals of this plant were found adjacent other species of plants and in places completely exposed to sun as well in moderate shade. On the same plant it was common to see both adults and nymphs of $Z$. versicolor, from November to May. In March and April, along with the flowering of B. rubifolia, it was common to see adults of $Z$. versicolor on the flowers (Figures $1-3,5)$, where they preyed upon insects attracted to them. Prey observed were small flies, beetles and more frequently Meliponini bees (Figures 1-2, 4). As an additional record, a female with a Tachinid egg attached on its scutellum was observed (Figure 3). Few records of Tachinidae parasitizing Reduviidae are known (GIL-SANTANA \& ForERO 2010). Unfortunately, as no adult fly could be obtained, it was not possible to identify the tachinid species, but it is likely a Phasiinae.

The data obtained in the field showed that $Z$. versicolor is associated with $B$. rubifolia. Although a clear advantage of the association observed to $Z$. versicolor is the source of prey in the flowers, the species was also persistently found in other months with no flowering, always only on B. rubifolia and not on surrounding vegetation.

Insects require sterols for their growth and development but they are not able to synthesize them (CLARK \& BLOCH 1959). The Asteraceae are a large plant family known to synthesize an impressive variety of compounds, and at least some are a known source of sterols (NIÑo et al. 2006), diversely metabolized by different insects (JANSON et al. 2009). Sterols are synthesized by at least one species of Bidens (KHAN et al. 2001). Only more extensive future fieldwork would clarify if the significance of the

association observed between $Z$. versicolor and $B$. rubifolia is restricted to prey on its flowers or includes other advantages, such as sterols, to the reduviid.

\section{REFERENCES}

Bérenger, J.-M. \& D. Pluot-Sigwalt, 1997. Relations privilégiées de certains Heteroptera Reduviidae prédateurs avec lês végétaux. Premier cas connu d'un Harpactorinae phytophage. C. R. Académie des Sciences Paris, Sciences de la vie, 320: 1007-1012.

Capriles, J.M., 1990. Systematic catalogue of the Reduviidae of the World. Caribbean Journal of Science, Special publication N. 1. Puerto Rico, University of Puerto Rico, 694p.

Clark, A.J. \& K. Bloch, 1959. The absence of sterols synthesis in Insects. The Journal of Biological Chemistry, 234: 25782582.

Forero, D., H.R. Gil-Santana \& P.H. van Doesburg, 2008. Redescription of the Neotropical genus Aristathlus (Heteroptera, Reduviidae, Harpactorinae), p. 85-103. In: Grozeva, S. \& N. Simov (Eds.). Advances in Heteroptera Research, Festschrift in Honour of 8oth Anniversary of Michail Josifov. Sofia-Moscow, Pensoft Publishers, 417p.

Gil-Santana, H.R. \& D. Forero, 2009. A new species of Notocyrtus, a new synonym of Coilopus, and new records and notes on other Harpactorini (Hemiptera: Heteroptera: Reduviidae: Harpactorinae). Zootaxa, 2148: 55-67. Preview available at http://www.mapress.com/zootaxa/2009/f/z02148po67f. pdf.
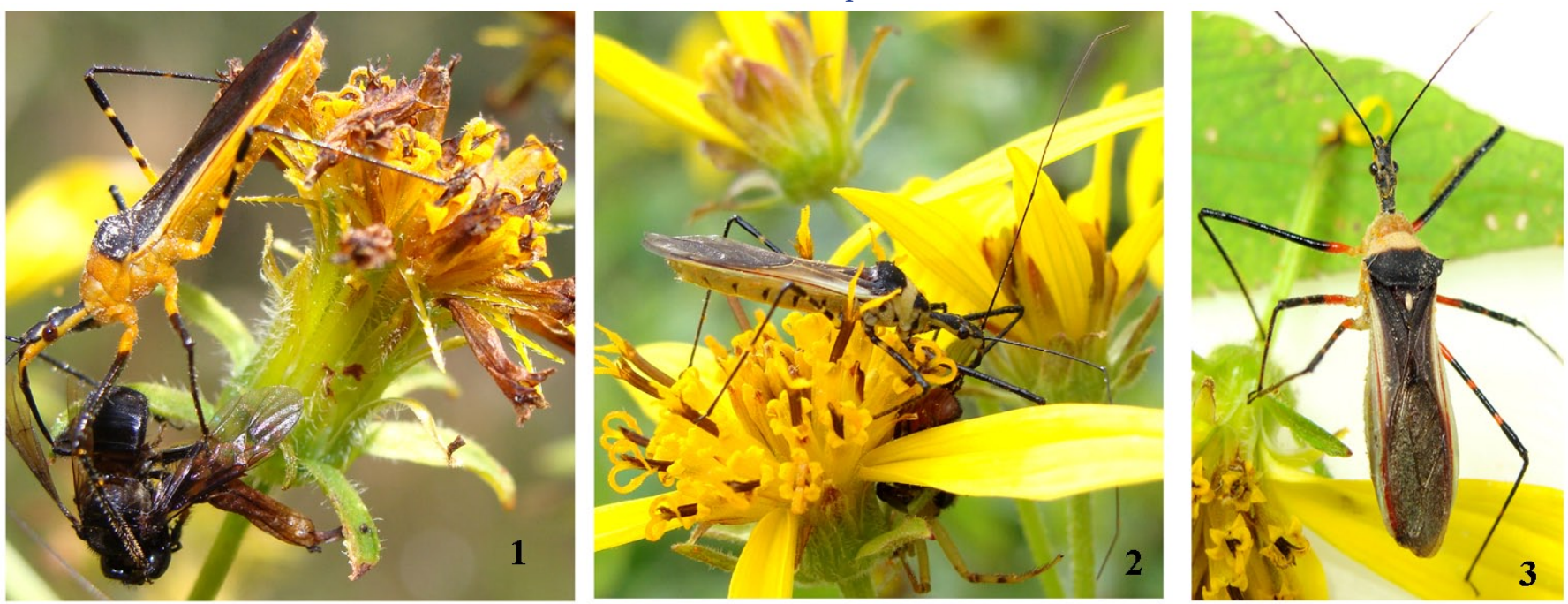

Figures 1-3. Zelus versicolor (Herrich-Schäffer), females on flowers of Bidens rubifolia Kunth: (1) preying a Meliponini bee; (2) preying a Meliponini bee, which is being attacked also by a small spider under the flower; (3) with a tachinid egg attached in its scutellum.
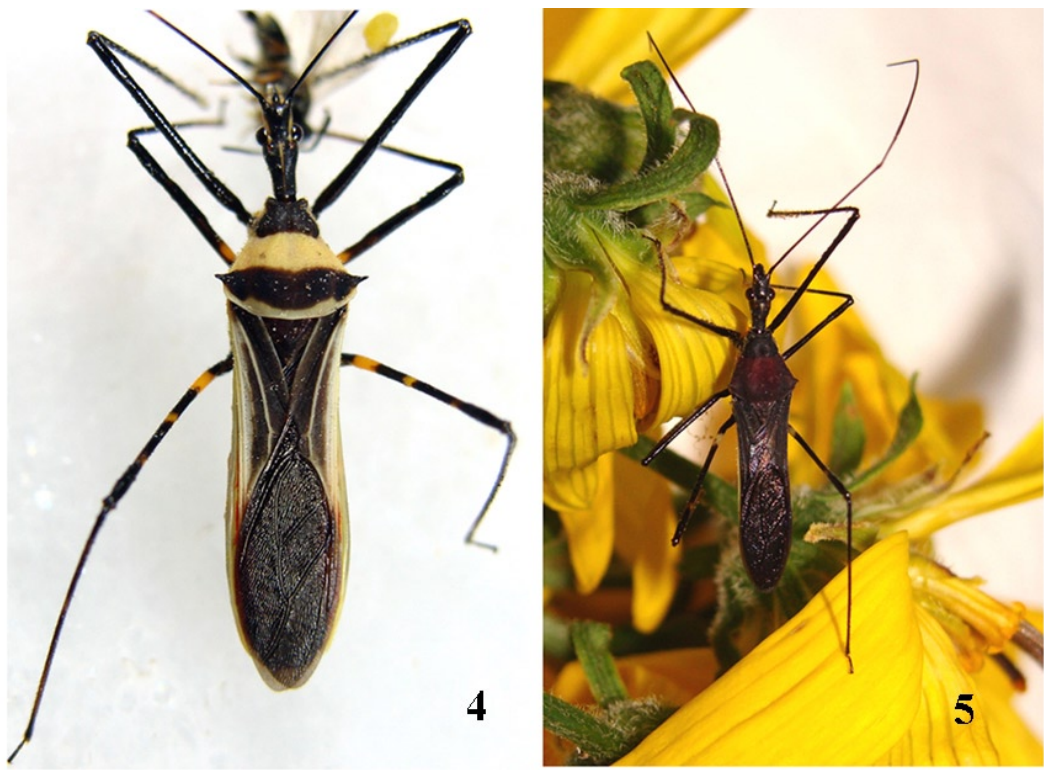

Figure 4-5. Zelus versicolor: (4) female preying a Meliponini bee; (5) male on flowers of Bidens rubifolia Kunth. 
Gil-Santana, H.R. \& D. Forero, 2010. Taxonomical and biological notes on Neotropical Apiomerini (Hemiptera: Heteroptera: Reduviidae: Harpactorinae). Zootaxa, 2331: 57-68. Preview available at http://www.mapress.com/zootaxa/2010/f/ z02331p068f.pdf.

Gil-Santana, H.R., 2008. New records, and nomenclatural and biological notes on Reduviidae (Hemiptera: Heteroptera) from Bolivia and Brazil. Zootaxa, 1785: 43-53. Preview available at http://www.mapress.com/zootaxa/2008/f/ z01785p053f.pdf.

Hart, E.R., 1972. A systematic revision of the genus Zelus Fabricius (Hemiptera: Reduviidae). PhD Dissertation, Texas A \& M University, College Station, 595 p.

Hart, E.R., 1986. A systematic revision of the genus Zelus Fabricius (Hemiptera: Reduviidae). Genus Zelus Fabricius in the United States, Canada and Northern Mexico (Hemiptera: Reduviidae). Annals of the Entomological Society of America, 79: 535-548.

Hart, E.R., 1987. The genus Zelus Fabricius in the West Indies (Hemiptera: Reduviidae). Annals of the Entomological Society of America, 80: 293-305.

Herrich-Schäffer, G.A.W., 1848. Die wanzenartigen Insekten. Nürnberg, Achter Band. 130 p.

Como citar este artigo:

H.R. Gil-Santana \& R.J.V. Alves, 2011. Association between Zelus versicolor (Herrich-Schäffer) (Hemiptera, Reduviidae, Harpactorinae) and Bidens rubifolia Kunth (Asterales, Asteraceae). EntomoBrasilis, 4(1): 30-32. www.periodico.ebras.bio.br/ojs
Janson, E.M., R.J. Grebenoik, S.T. Behmer \& P. Abbott, 2009. Same host-plant, Different Sterols. Variation in Sterol Metabolism in an Insect Herbivore Community. Journal of Chemical Ecology, 35: 1309-1319.

Khan, M.R., M. Kihara \& A.D. Omoloso, 2001. Anti-microbial activity of Bidens pilosa, Bischofia javanica, Elmerillia papuana and Sigesbekia orientalis. Fitoterapia, 72: 662665.

Miller, N. C. E., 1956. The biology of the Heteroptera. London, Leonard Hill.162 p.

Niño, J., D.M. Narváez, O.M. Mosquera \& Y.M. Correa, 2006. Antibacterial, antifungal, and cytotoxic activities of eight Asteraceae and two Rubiaceae plants from Colombian Biodiversity. Brazilian Journal of Microbiology, 37: 566-570.

Schuh, R.T. \& J.A. Slater, 1995. True bugs of the World (Hemiptera: Heteroptera). Classification and natural history. Ithaca, Cornell University Press, 336p.

Recebido em: 22/06/2010

Aceito em: 17/11/2010
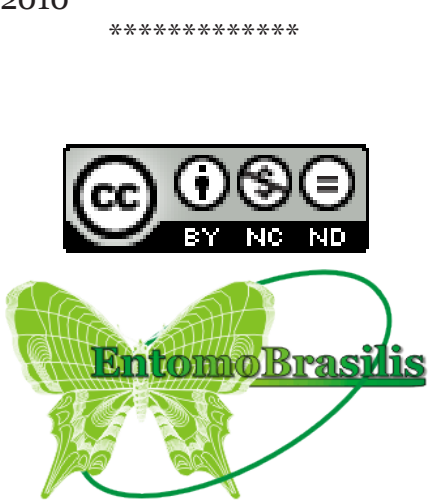